Article

\title{
How Social Media Can Foster Social Innovation in Disadvantaged Rural Communities
}

\author{
Kenichiro Onitsuka \\ Graduate School of Global Environmental Studies, Kyoto University, Kyoto 606-8501, Japan; \\ onitsuka@kais.kyoto-u.ac.jp; Tel.: +81-75-753-6158
}

Received: 23 March 2019; Accepted: 6 May 2019; Published: 12 May 2019

\begin{abstract}
Social innovation has received widespread attention in the rural development field, especially its contribution to future rural sustainability. Social innovation revolves around social networks. Rural areas, however, can be relatively disadvantaged by their geographical peripherality. Social media, therefore, has strong potential to foster social innovation by enabling remote communication, but in rural areas, social media use may be low because of an aging and decreasing population. This study examined community-level adoption and use of social media in rural areas in Japan, with a focus on Facebook, for the purpose of sharing community information and facilitating networking with a variety of actors to promote rural social innovation. The study involved a comprehensive search and case studies targeting 139,063 rural communities and 10,922 rural joint-communities, all of which are legally designated agricultural communities throughout Japan. The search found that disadvantaged rural communities' adoption of Facebook was scarce, and most of the communities that had adopted Facebook did not expand their social networks. Furthermore, investigation into the communities that had adopted social networking to a larger extent revealed that external supporters or migrants had essential roles in successful networking. Based on the obtained findings, this study has provided insights for future policy design.
\end{abstract}

Keywords: social innovation; social media; digital divide; disadvantaged rural community; comprehensive survey; Japan

\section{Introduction}

In Japan, rural communities are rapidly aging and shrinking, losing resources and the ability to maintain regional sustainability without external support. In parallel, social innovation has received wide attention for its role in rural development in developed nations, which is well-exemplified by the EU's LEADER program [1] or recent Japanese rural development programs. Social innovation revolves around local or extra-local social networks [2,3] and communication is a key element in agricultural and rural innovation systems [4]. Rural areas, however, can be relatively disadvantaged by their geographical remoteness or peripherality. Information and communication technology (ICT), therefore, has a strong potential to foster social innovation by enabling interactive communication and networking, which is free from the restrictions of time and space characteristic of traditional networking [3]. ICT has rapidly spread, dramatically changing communication and information-sharing all over the world. On a macro level, a growing number of rural residents have gained online access thanks to the widespread adoption of portable devices, such as smartphones and both wired and non-wired connections. ICT is now considered to be essential to current rural development in which neo-endogenous or nexogenous approaches, incorporating diverse internal and external actors, are addressed [3,5], as well as to the future sustainable rural communities. Rural realization of the benefits of ICT, however, remains limited, resulting from the "digital divide" or "digital inequality" [6]. Previous studies have shown that many 
rural areas still lag behind their urban counterparts regarding Internet connectivity [7] and need to pay a "rural penalty" [8], though now the digital divide extends beyond the issue of connectivity [9-12].

In many relevant studies, the digital divide and digital inequality are considered individual-level issues since ICT is expected to contribute to a better everyday life for individuals (i.e., people use ICT for a variety of purposes, both at work and at home) [13]. The digital divide and digital inequality at the enterprise level [14] or regional level [15] have also been examined in the rural setting, but studies focusing on this issue at the rural community level have been scarce. Since social innovation takes place as a co-evolutionary learning process occurring in networks [16], the innovation process cannot begin if external actors cannot recognize communities' situations due to a lack of proactively shared community information. Information-sharing at the rural community level, therefore, is important. Each community has its own culture, system, and challenges. As such, community-level adoption or use of ICT should take into account these unique aspects rather than merely focusing on use at the individual level to derive the greatest benefit for the whole community. Online information is particularly essential for collaboration with remote actors [17]. On the other hand, the community-level digital divide is linked to the individual level since a lack of individuals motivated to promote community revitalization or community information-sharing would delay the community's plan and success of going online. In addition, disadvantaged rural communities located in remote or peripheral areas, including in Japan, have a higher proportion of older people and lower Internet adoption and literacy rates, which can make it difficult for these communities to voluntarily start using ICT for community information-sharing $[15,18]$. As such, two key questions should be asked to promote rural online access, as follows: (1) Who can take on the responsibility of information-sharing in a disadvantaged rural community? (2) How can these people be identified and made available?

This study focuses on community-level adoption and use of ICT in rural areas, with a special focus on Facebook (as a representative example of social media), for the purpose of sharing community information and facilitating networking with a variety of actors to promote social innovation. This study, in particular, focuses on disadvantaged rural communities throughout Japan, which is the fastest-aging country in the world with high Internet connectivity, even in rural areas. By learning from the cases that have adopted Facebook to facilitate regional advantages, this paper will provide practical information useful for proposals regarding the use of social media for rural community benefit and for policy design considering ICT for future sustainability in rural areas. It presents comprehensive data targeting Japan's disadvantaged rural communities regarding their ICT use. Such information at the national level is not currently available, either for Japan or other countries.

\subsection{The History and Issues of Rural Informatization in Japan}

Since the formulation of the e-Japan initiative and the enactment of the information technology (IT) basic law in 2001, as well as the formulation of the 2006 u-Japan initiative that followed the e-Japan initiative, Internet connectivity has rapidly improved throughout the country; the Internet penetration rate reached $83.5 \%$ as of 2016. However, a gap in Internet usage between people aged 65 and over and younger people still exists [18]. The percentage of households living in areas where ultrafast wired (e.g., fiber to the home (FTTH)) or wireless (e.g., Long-Term Evolution (LTE)) broadband connection are available reached $99.0 \%$ and $99.8 \%$, respectively, as of 2017 [19]. Although these are best-effort services, which refers to network service without a guarantee that service will be free of communication packet errors or transmission delays, they provide sufficient connection speed for social media use throughout Japan. While connectivity has improved, Internet adoption rates in rural areas still lag behind those in urban areas [20], partly resulting from a higher percentage of people over 65 who live in rural rather than urban areas ( $31.0 \%$ vs. $24.2 \%$ in 2015 , respectively). In line with the e-Japan initiative, local ICT seminars were held, mainly by local governments, across the country for the purpose of improving public information literacy. The Ministry of Agriculture, Forestry, and Fisheries (MAFF) also adopted "informatization" as a policy in the field of agriculture, and, in 2003, the "e-muradukuri plan," or rural community development plan through ICT, was launched. In 2009, ICT Restoration Vision 
was announced by the Ministry of Internal Affairs and Communications (MIC) and agriculture with delayed progress in informatization was noted as one of its priority areas. Although some evidence for the impacts of these programs has been reported empirically, in disadvantaged rural areas with a high proportion of older people, rapid changes to both hardware and software has left them still in need of education and support to utilize these new advantages. This is considered a barrier, even though recent technological innovations, while changing quickly, do offer more intuitive usage (e.g., touch screen, speech recognition, and handwriting input). From a technical perspective, it has gotten easier for older people to access and use ICT.

Social networking services (SNSs), represented by social media platforms like Mixi (the most popular domestic SNS) and custom SNSs developed for activating regional communication, started in 2004 and have become increasingly popular nationwide. Facebook, the largest SNS in the world, and Twitter started their services in Japan in 2008. At first, Facebook was expected to struggle in the Japanese market, owing to cultural values of privacy and security, since it requires that real names be used. However, real names and real pictures increased the perception of trustworthy and transparent information, so it has been used for official communication by both public and private organizations. Since around 2011 when Facebook started becoming popular nationwide, a growing number of municipalities and rural communities have adopted these two SNSs for regional promotion and information dissemination. Now, Facebook is one of the most popular SNSs in Japan with about 26 million users as of 2015 [21]. Since many rural areas were suffering from the effects of an aging and declining population, it was expected that SNSs would have a groundbreaking role in establishing a collaborative network with external actors. While Facebook has been adopted in rural development projects in Japan (see Section 1.2.4), actual adaptation and its effects on rural sustainability have never been examined.

\subsection{Literature Review}

\subsubsection{Social Innovation in Rural Development}

In classical economic theory, innovation is considered a new combination of new elements not seen in previous economic systems [22]. This is connected to the current common understanding of social innovation. The term "social innovation" has been a buzzword in general [23], as well as in rural development [24]. Nonetheless, the definition is both ambiguous and diverse. Thus, in contrast to social innovation's popularity and importance in rural development practices and policies, scant attention has been paid to it in academic studies. To build the groundwork for its academic discussion, attempts to determine the concept's theoretical definition have been carried out $[2,24]$.

Neumeier [2] defined social innovation as "changes of attitudes, behavior, or perceptions of a group of people joined in a network of aligned interests that, in relation to the group's horizon of experiences, lead to new and improved ways of collaborative action within the group and beyond" (p. 55). Some aspects of the definition imply that social innovation is based on the collaboration of diverse actors within and outside a group or process, which is consistent with neo-endogenous (bottom-up) or nexogenous (mix of top-down and bottom-up) development strategies emphasizing multi-actor collaboration [3]. Moreover, social innovation has two characteristics: First, social innovation produces or enhances social capital. Second, social innovation has both a process dimension and an outcome dimension [25]. The process dimension, which includes mobilizing actors or participation of actors, is particularly important because it is strongly intertwined with the outcome [25].

Since social networking is the most important element in social innovation, some empirical studies have adopted a social network approach. They have indicated that a social network, including producers and consumers, instigates innovations [26], that innovative power of rural social enterprises to connect rural communities with supra-regional networks and their intermediary role facilitates social innovation [27], and that community leaders and key actors have developed networks for support or advice from other communities [28]. Furthermore, external urban factors and cross-border 
constellations of actors influence rural social innovation [29]. While the roles of external actors have been confirmed in various studies, the number of relevant empirical studies related to social innovation is still limited.

\subsubsection{Knowledge Management and the Roles of ICT in Innovation}

Knowledge is the source of innovation, and a theoretical model of knowledge creation to promote innovation called the SECI model, which stands for socialization, externalization, combination, and internalization, has been introduced [30]. This model explains the process in which tacit (knowledge embedded in the human mind through experience that is difficult to transfer) and explicit knowledge (knowledge codified and digitized in different forms that is easy to transfer) are converted into organizational knowledge and innovation, including two stages for sharing knowledge, socialization (tacit to tacit) and combination (explicit to explicit). Socialization commonly needs face-to-face interaction in a community of practice [31], while ICT has great potential for combination by its characteristic sharing of information and knowledge in a variety of explicit formats, such as text, still images, moving images, 3-D models, and virtual reality (VR)/augmented reality (AR). In initial knowledge-management practice, a variety of information systems that enable knowledge-storing and sharing in an organization were adopted. However, those information systems seldom worked due to the lack of motivation for sharing individual knowledge [32]. Thus, a motivation-enhancing milieu in an organization, which is connected to social capital [33], has been necessary for successful knowledge management, known as the second generation of knowledge management [32]. Many studies have confirmed that social capital can be created through online networks [34,35]. ICT has become essential again, not only as a system to share knowledge, but also as a platform for people to interact with each other $[17,36]$. A number of studies have examined impacts of online communication on knowledge management, but empirical studies in the rural development context have not been found.

\subsubsection{ICT Studies in the Rural Development Context}

In today's networked society characterized by people connecting using communication technology [37], the lack of access to resources is explained as resulting from a lack of connectivity rather than geography [3]. The lack of connectivity in rural areas, known as the urban-rural digital divide, has existed for decades $[7,38,39]$. Previous studies have noted the paradox that "rural communities are most in need of improved digital connectivity to compensate for their remoteness, but they are least connected and included" [6] (p. 360). Lower densities and greater distances in rural areas discourage the market from investing in new technologies there $[8,40]$. Relevant studies focusing on ICT in the rural development context are categorized into two major strands, connectivity research (supply side) and inclusion research (demand side) [6]. While connectivity, especially broadband connectivity, has positively impacted income or job opportunities [41], the sustainability of business and other lifestyle activities [42], and individuals' resilience or control over everyday activities [13], recent empirical studies still have reported insufficient connectivity in rural areas in comparison to their urban counterparts [43].

In its early stages, inclusion research was based on criticism for the oversimplified conceptualization of the digital divide, focusing on connectivity. As penetration has increased, the focus in digital divide theory has shifted from the dichotomous view (the first-level digital divide) between "haves" and "have-nots" to a variety of other factors impacting the digital divide, including autonomy of use [44], motivation [11], skill [11,44], purpose [44], social support [9,44], and use [9-11,45]. These are referred to as the second-level digital divide. In the 2010s, there were a growing number of empirical studies examining the impacts and challenges of ICT use beyond connectivity in the rural development context. According to those studies, even though the connection was available, a certain proportion or type of rural residents did not use ICT [46-48] and their use did not lead to economic benefit [49]. Other recent studies have focused on social media that enables users to be both creator and consumer of web content. Furthermore, social media is expected to facilitate social capital and social innovation through 
communication among a variety of actors, within and outside a community [50]. According to relevant studies, social media use is still in its initial phase in rural areas and the realization of social capital on social media as multi-stakeholder platforms is limited [50,51]. The Internet's characterization by rural residents, not as a place to meet new people, but as a place to communicate with people whom they already know was also observed [51].

The creative economy has also received academic attention in its use of ICT as its members seek a better quality of life or creative inspiration away from cities. Thus, creative migrants are expected to contribute to rural community resilience [52]. Research from Scotland has found that creatives need digital capital based on broadband infrastructure, so infrastructure should be prioritized [53,54], and that creatives should be employed as community resources for delivering digital inclusion strategies because they would make good digital intermediaries [52].

While the above studies have focused on individual-level issues, some studies have investigated issues at the organizational or enterprise level. Townsend, Wallace, Smart, and Norman [55] revealed that microenterprise owners actively developed social capital through online networking, focusing more on bridging social capital than bonding social capital. It was also reported that Internet portal sites worked well as forums for a variety of network actors of small rural firms [56]. However, studies on individuals who play an important role in organizational adoption and utilization of ICT have not been found.

\subsubsection{The Roles of ICT for Rural Development in Japan}

In Japan, studies focusing on ICT in the rural development context first appeared in the early 2000s when broadband and mobile connections began to spread throughout Japan. However, the number of these papers was limited. After SNSs appeared in 2004, a growing number of studies focusing on social media have been done in various fields; however, in the field of rural development, social media did not appear in academic debates until the world's largest SNS, Facebook, became popular in Japan around 2011.

The focus of relevant Japanese studies is in line with international discussions, which mainly examined connectivity and inclusion, and most remained at the case-study level. Issues of digital divide between urban and rural areas have been reported in national surveys as well, citing the following factors for digital divide at the regional level: Gaps in socioeconomic scale, availability of organizations that support regional informatization, gaps in levels of political support [57], and a lack of opportunities to learn about the Internet among older rural inhabitants [58]. To close the divide between urban and rural areas, the process of diffusion of social media in rural areas has been studied. For example, some papers have suggested that a specific strategy should be considered for specific groups, categorized according to their attributes by employing innovation diffusion theory $[59,60]$. In addition, the level of motivation and capacity for organizations to stimulate diffusion are influencing factors [61]. Key people (e.g., opinion leaders) will ideally assume roles in networking and should be utilized to activate the network [62]. Existing studies that do focus on the relationship between ICT use and sense of community show an inverted situation in which younger residents adopted the Internet but used it only for personal purposes, showing low motivation for community revitalization, while older residents rarely adopted the Internet but had strong motivation for community revitalization [63]. These findings suggest that fostering a sense of community among younger people in tandem with providing learning opportunities for older people is required.

\subsubsection{Summary and Study Scope}

After summarizing the relevant literature, this study developed a theoretical process of social innovation through ICT (see Figure 1). 


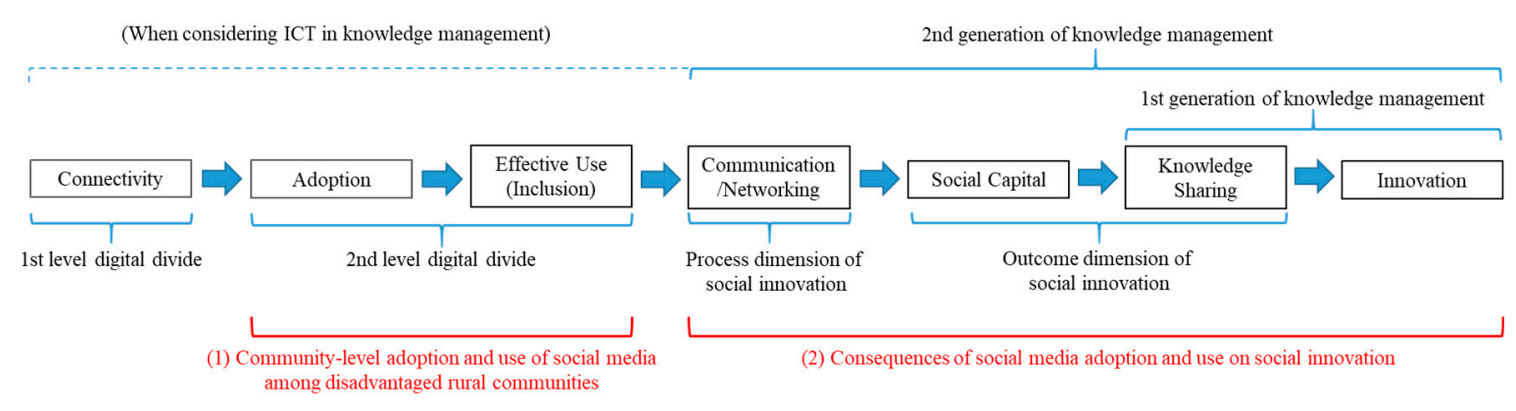

Figure 1. The theoretical process of social innovation through ICT.

This process shows that ICT, especially social media, can be an important milieu for social innovation. This is particularly true in rural communities located in peripheral areas, since ICT provides powerful networking power that can lead to social capital without temporal and geographical restrictions. However, most of the relevant studies have focused on the situation or challenges within a community or a region. Furthermore, studies focusing on the community level are limited. A comprehensive geography of the digital divide in rural settings at the national level is rare. To address the shortcomings of past studies, this study primarily examined (1) the community-level adoption and use of social media with a special focus on disadvantaged rural communities throughout Japan. This study further complements these findings by examining (2) the consequences of social media adoption and use and its contribution to fostering social innovation.

\section{Materials and Methods}

\subsection{Targeted Communities of This Study}

This study targeted all rural communities within disadvantaged areas according to Japanese laws (see Section 2.4). The minimum unit of a rural area is called a shuraku in Japanese, which means "agricultural community." There were 139,063 shurakus in Japan as of 2010 [64]. Before World War II, inhabitants engaged in cooperative agricultural activities within a shuraku, resulting in solidarity among these communities. However, migration of the younger generation from rural to urban areas for education or job opportunities has facilitated the rapid aging and depopulation in shurakus, leading to serious sustainability issues.

A community is the basic environment for everyday life of its inhabitants, though some public and private services, such as elementary schools, are offered to a broader range of individuals through what is called a kyuson, or former municipal district. Kyusons are based on municipal demarcations from 1950, before several mergers took place. A former municipal district consists of several shurakus, which in many cases correspond to current elementary school district. Therefore, kyusons are still important in the everyday lives of community inhabitants, even though they are no longer official administrative districts. After the latest large-scale municipal mergers took place in the 2000s, current municipal districts are often considered too large for rural development, whereas the former municipal districts are considered of suitable size for planning. Many rural inhabitants still recognize kyuson as communities, as well. There were 10,922 kyusons as of 2010 in Japan [64]. I considered both shurakus and kyusons as rural communities for the purposes of this study. The average populations are different between shurakus and kyusons. Furthermore, their areas can overlap and residents can consider both of them as communities. Thus, it is not appropriate to mix them and I analyzed them separately in this study. For differentiation and easier reference, we use the term "community" for shuraku and "joint community" for kyuson.

\subsection{Research Questions and Study Procedure}

This study developed a theoretical process of social innovation that includes the two aforementioned aspects (see Figure 1). As for connectivity, most rural communities have at least 
one option to connect to the Internet, which is sufficient for social media use in Japan, so this study did not consider this particular issue. As will be seen, this study set three research questions for (1) analysis of community-level adoption and use of social media among disadvantaged rural communities (RQ1-RQ3) and one research question for (2) analysis of the consequences of social media adoption and use (RQ4).

Japan is the country with the most rapidly aging population, which has been found to contribute to digital divide, and the digital divide between Japan's urban and rural areas has been observed in past studies [57,58]. However, Internet use has become more common for older people [65] and it is assumed that some older inhabitants in rural areas adopt social media for community benefits. Thus, I raised the following research question:

(RQ1) Is overall adoption of Facebook still low in disadvantaged rural (joint) communities?

After social media is adopted, there are many hurdles for its effective use, as indicated in the studies regarding the second-level digital divide [9-11,44]. It is still considered to be hard for older rural inhabitants to use social media effectively for expanding their networks, without support or skill development, after adoption. Thus, I raised the following research question:

(RQ2) After social media adoption, is the overall use of Facebook still not effective for strengthening community relationships in disadvantaged rural (joint) communities?

A community that adopts and uses social media effectively is considered to have people within or outside the community who are key to that use. For this hypothesis, this study uses concepts from Rogers' innovation diffusion theory [59], wherein people are categorized into five types according to speed in adoption of innovation. Although studies on diffusion of innovation often consider individual levels of adoption within a specific organization or region, not every inhabitant within the community needs to adopt the innovation to share community information or knowledge on social media, which therefore promotes social innovation. Even if only a few people adopt the innovation and use it for community benefits, I consider that the community as a whole adopted the innovation. This study, therefore, has a special focus on innovators, the earliest insiders adopting innovation, and change agents, outsiders with a high level of skills, knowledge, and experiences in terms of the specific innovation, who introduce and diffuse innovation to organizations or communities. Thus, I raised the following research question:

(RQ3) Do internal and/or external key actors provide opportunities or take on roles for adoption and effective use of social media?

According to Figure 1, communities using social media can vitalize communication or networking, mainly through outsiders, since a Facebook page is a portal site that provides an open forum to anyone [56]. These pages are not only a communication space but rather facilitate social capital creation and knowledge-sharing (outcome dimension of social innovation) to promote innovation. With this in mind, I raised the following research question:

(RQ4) Does use of social media lead to vital communication/networking among insiders and outsiders, facilitating social capital creation and knowledge-sharing?

Figure 2 shows the procedure of this study (see Sections 2.3-2.5 for the details of each step), which focused on Facebook pages run by disadvantaged rural communities. 


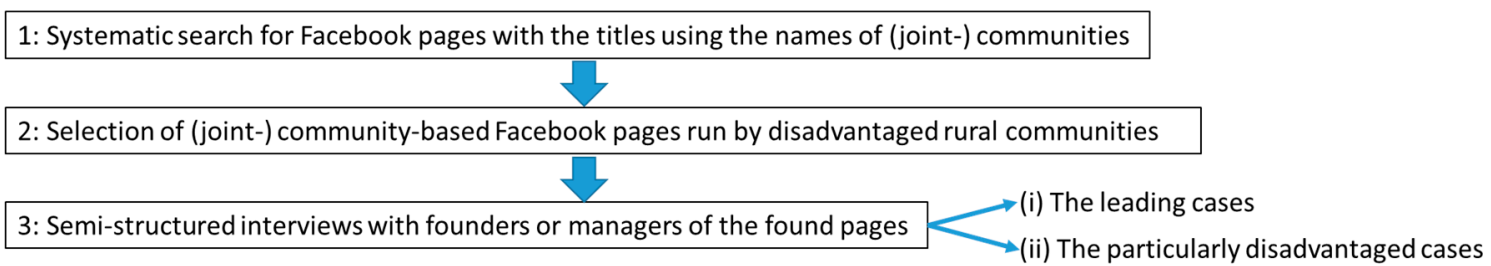

Figure 2. Study procedure.

\subsection{Systematic Search for Facebook Pages with Titles Using Community or Joint-Community Names}

This study focused on Facebook as a representative of social media since, empirically, Facebook has been most widely used for promotion and information dissemination by both private and public organizations in Japan, although no formal studies have confirmed this. It is considered trustworthy and transparent, compared with other social media such as Twitter, because it requires the use of real names. Previous academic literature regarding ICT use for rural development has used case studies or analyzed national data. However, national data in terms of ICT use at the (joint) community level are not available in Japan as in other countries like the UK [15]. Thus, I needed to identify all rural (joint) communities that run (joint) community-based Facebook pages in Japan. First, I identified all the designated (joint) communities in Japan, including (joint) communities considered not legally disadvantaged, then excluded irrelevant data (see Section 2.4 for details). As manual searching of about 150,000 pages was considered unrealistic, I used the paid service Google Site Search, which provides users an application programming interface (API) to pragmatically manipulate Google search functions. I conducted the systematic search by developing Java-based software that could automatically read each of the search keywords from a prepared list, including keywords for all (joint) communities, and then search for (joint) community-based Facebook pages through Google Site Search. After running the search, the software automatically saved the top 10 search results as CSV (comma-separated values) files according to the found (joint) community's assigned prefecture. I decided to use the following search keywords:

- Name of current municipality (blank) name of a (joint-) community belonging to the current municipality.

After several rounds of validation through comparisons with a manual search targeting the Kyoto prefecture, I confirmed that more than $90 \%$ of Facebook pages run by rural communities could be found this way.

To reduce the return of irrelevant results, I used the municipality name first because there were cases in which the names of (joint) communities were the same as names used by individuals or specific places. I also set targeted domains to limit the search results to directories under "https://www.facebook.com/" and "https://ja-jp.facebook.com/," the latter of which is the specific domain for Japanese Facebook pages. The systematic search was conducted in January 2015.

\subsection{Selection of (Joint) Community-Based Facebook Pages Run by Disadvantaged Rural Communities}

After running the systematic search, the results still contained a number of irrelevant pages. As such, in order to select only the appropriate results among the found Facebook pages, I checked the results one by one using criteria of whether or not they were disadvantaged community-based pages. The selection was conducted in three steps.

In the first step, I checked page titles of all results manually and removed the pages owned by individuals, private companies, and pages whose titles did not contain the name of the (joint) community. This is because visitors would not be able to recognize the purpose of pages that did not include the name of (joint) communities. In the second step, I removed the pages of (joint) communities that were not categorized as being in disadvantaged areas by referring to five national laws that define these areas across Japan (see Table 1). 
Table 1. Definitions of disadvantaged areas by Japanese national laws and numbers of designated municipalities as of 2018. The total number of municipalities in Japan was 1719 as of 2018. There were no big changes between in 2015 and in 2018.
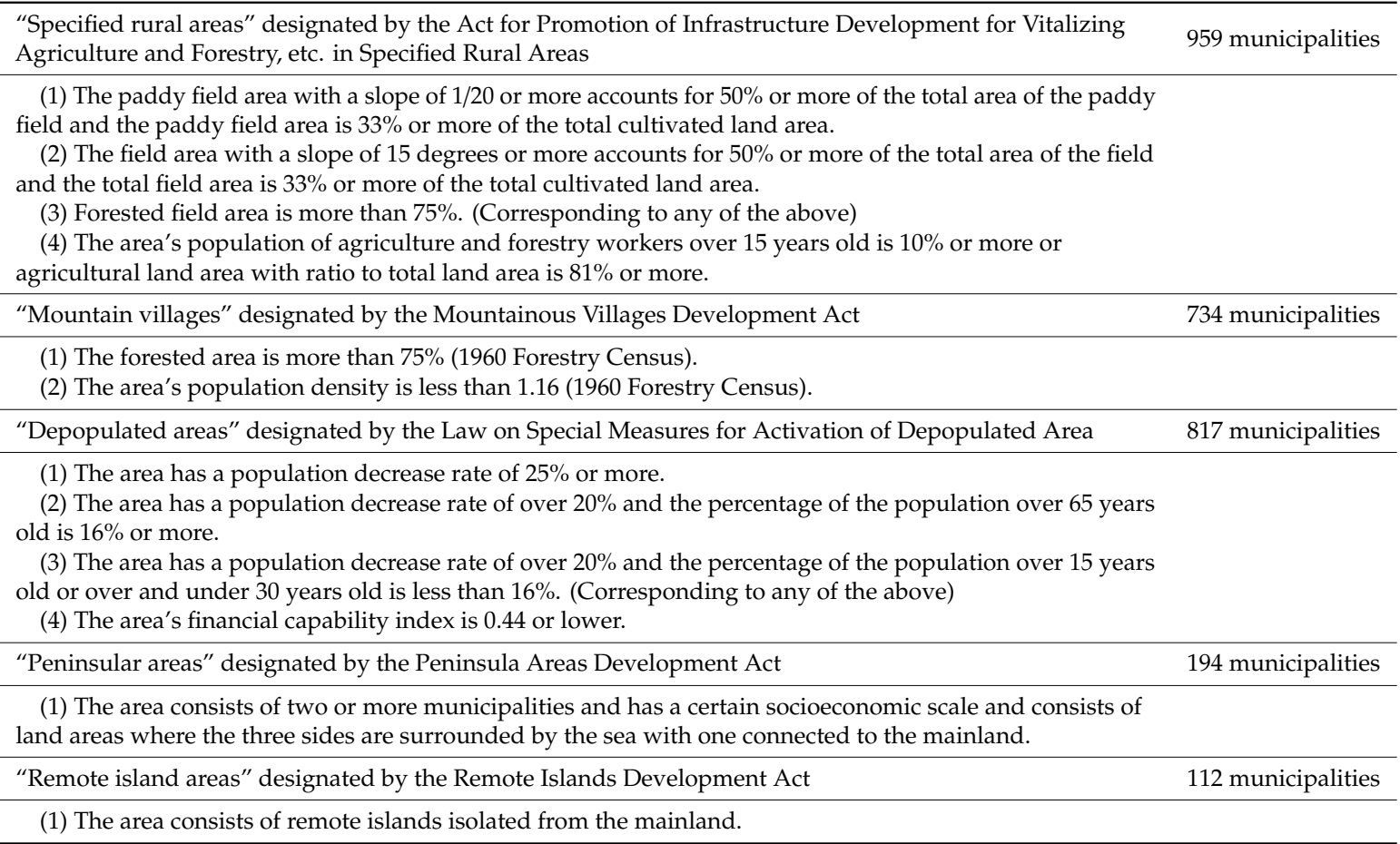
Source: Ministry of Agriculture, Forestry and Fisheries, Japan [66].

Using these laws, 76,165 out of 139,063 communities (54.1\%) and 5,528 out of 10,922 joint communities (50.6\%) were included. In the third step, I checked the remaining pages again by opening the pages one by one and checking the contents manually. I removed any that were owned by local groups, organizations, or governments for the purpose of sharing group-specific information rather than community information. Only a few pages were found to be owned by communities, organizations, governments, and the like to share community information. These were the pages used as the final results.

\subsection{Semi-Structured Interviews}

After the systematic search and selection of the targeted Facebook pages, I conducted semi-structured interviews to further understand the current situation of (joint) community-based Facebook use cases by disadvantaged (joint) communities. First, I visualized distributions of the number of page "likes" as of March 2015, which revealed the number of page fans who could see information as updated by the community in real time. This study used page "likes" as an indicator of networking and communication resulting from adoption and use of Facebook. Besides, it is considered that page "likes" are not sufficient as an evidence of actual networking and communication. I asked key individuals about effects of Facebook in networking and communication in detail in the semi-structured interviews (explained later) to complement page "likes".

Afterward, I carried out further selection of (joint) communities that managed their own (joint) community-based Facebook pages from the following two perspectives:

1. The leading cases: Pages that had adopted and used Facebook for their home communities to a larger extent among all pages identified.

2. The particularly disadvantaged cases: Pages that were run by (joint) communities without external supporters and located in particularly disadvantaged areas. 
The leading case category was intended to identify common characteristics of the leading cases and discover any "lessons learned" for disadvantaged rural communities related to adopting and effectively utilizing Facebook. The particularly disadvantaged case category served as a supplementary analysis. I defined the disadvantaged areas as those that were more than $30 \mathrm{~min}$ by car from neighboring cities and had no official supporters via policy programs. Connected to RQ3 in Section 2.2, it was assumed that external actors might serve as change agents by providing opportunities for adoption and effective utilization or that there might have been policy programs to invite supporters to peripheral regions. It was necessary to focus not only on the leading cases but also on the (joint) communities that were not expected to have supporters, because those cases can offer insight into the endogenous ICT adoption in particularly disadvantaged rural (joint) communities. In those communities, insiders might have assumed roles in voluntarily adopting Facebook as a method of innovation.

Focusing on the pages selected, semi-structured interviews with key individuals who had founded and managed the Facebook pages were conducted to obtain detailed information regarding characteristics and factors facilitating the adoption and effective use of Facebook in their communities. If the original founders or managers were not available, I interviewed a secondary person who was knowledgeable about the time when the pages were launched and the process for updating them afterward. Each interview was about one hour long and they were conducted over the phone or in person between February 2015 and February 2018. Referring to the second-level digital divide studies [11,44], I asked about situations or challenges within the communities, what was involved with the founding of the Facebook pages, and personal information about the page managers, including personal attributes, history, skills, and knowledge. I also asked about the process of managing the Facebook pages as well as any consequences that may have resulted after their creation and diffusion.

\section{Results}

\subsection{Identified Rural Communities Managing Community-Based Facebook Pages}

After systematic search and selection, 117 and 130 pages were found as community-based and joint-community-based Facebook pages, respectively. For the found pages at the community level, the adoption rate among disadvantaged communities was $0.16 \%(117 / 75,165)$, and the average and median values of the number of "like" occurrences on the pages were 213.8 and 114.0, respectively. As for the found pages at the joint-community level, the adoption rate was $2.35 \%(130 / 5,528)$ and the average and median values of the number of "like" occurrences on the pages were 230.9 and 148.5, respectively. The locations of found pages at both the community and joint-community levels are shown in Figures 3 and 4. Both figures show locations on the map with current municipality-level borders because visualizing only community-level borders would be too small to be effective at this size. The colored areas show the current municipalities that include the found (joint) communities, and the color tones show the levels of the number of page "likes." These maps show that a large number of found communities were located on Japan's main island, particularly in the eastern areas around the Tohoku region, site of the Great East Japan Earthquake. The Chubu region also had a massive earthquake in 2004 and the corresponding Facebook pages had a relatively high number of "likes". The found communities were also located in the Kansai and Chugoku region, but the number of "likes" were smaller. The other three big islands, Hokkaido, Shikoku, and Kyusyu, had fewer pages and a smaller number of "like" occurrences.

The histogram of the number of "like" occurrences on the Facebook pages at the community level (Figure 5) shows that 50 pages (42.7\%) had fewer than 100 "likes" and that 78 pages (66.7\%) had fewer than 200 "likes." Only four pages (3.4\%) had more than 1000 "likes," and 11 (9.4\%) had more than 500 "likes." The histogram at the joint-community level also reveals similar trends, with 40 pages $(30.8 \%)$ having fewer than 100 "likes," and 85 pages (65.4\%) with fewer than 200 "likes" (see Figure 6). As above, only four pages (3.1\%) had more than 1000 "likes" and $10(7.7 \%)$ had more than 500 "likes." 


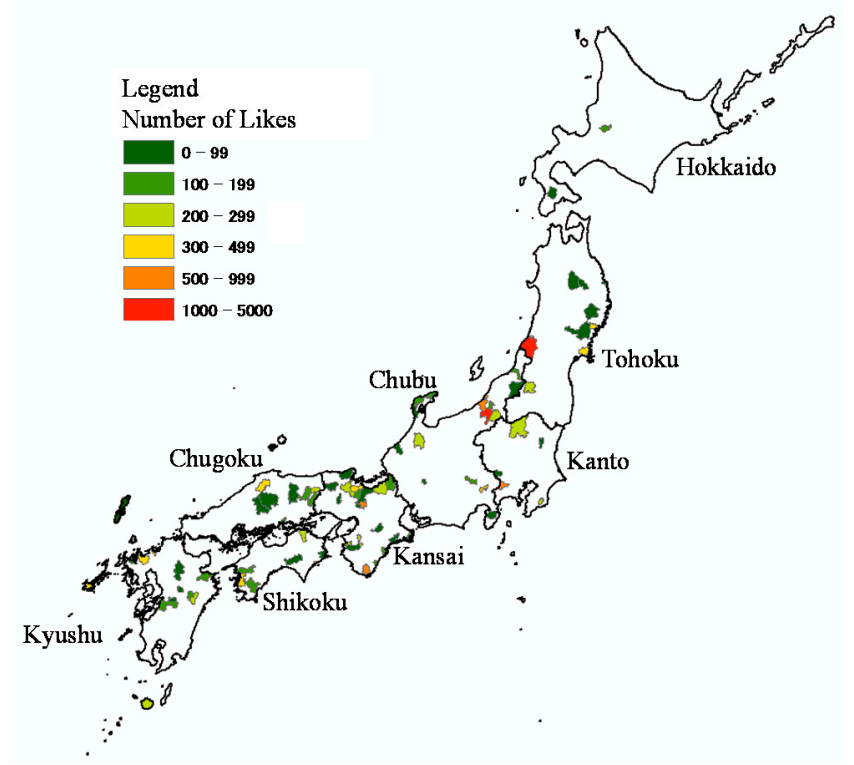

Figure 3. Geographical distributions of selected rural communities.

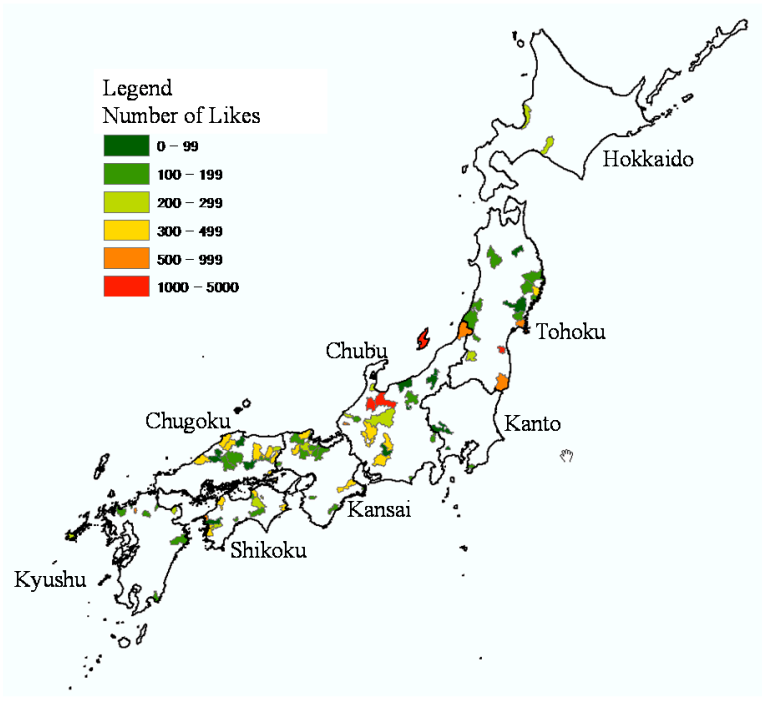

Figure 4. Geographical distributions of selected rural joint communities.

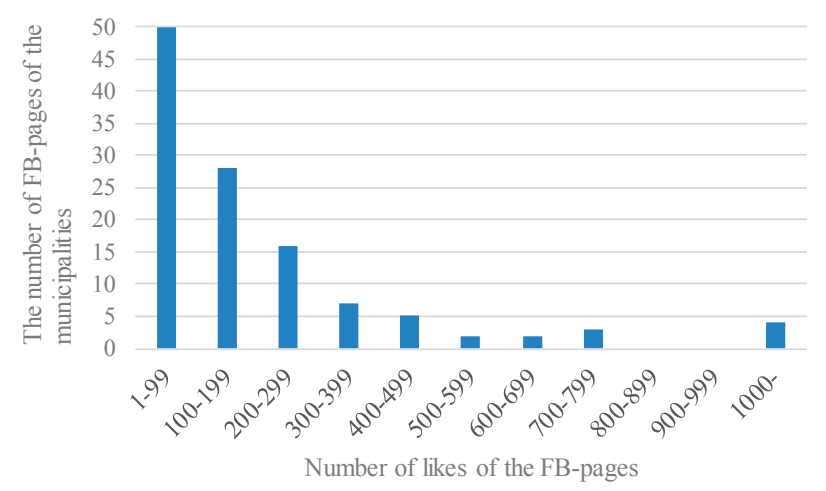

Figure 5. The histogram of number of "likes" on Facebook pages at the community level $(n=117)$. 


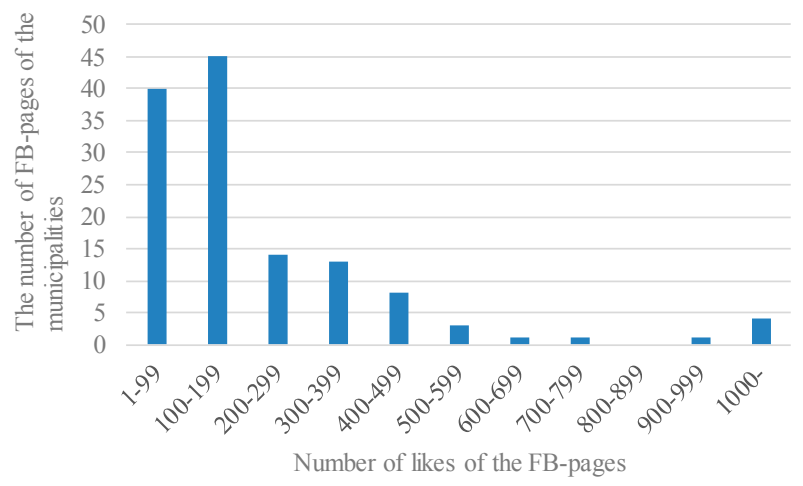

Figure 6. The histogram of number of "likes" on Facebook pages at the joint-community level $(n=130)$.

In total, we can see that (joint) community-based adoption of Facebook pages among disadvantaged rural communities in Japan is scarce. Even after adoption, effective utilization of the Facebook pages is considered rare, even among those innovative (joint) communities that appeared to have a successful start.

Population of the selected (joint) communities compared with leading cases (see Section 3.2) and particularly disadvantaged cases (see Section 3.3) is shown in Table 2. The average population of the selected communities is about 10 times bigger in joint-communities than in communities. The proportions of elderly people, who are aged 65 and over, are bigger than the proportion in the (joint) communities at the national level, as of 2015 (26.7\%), except leading cases of community, and are higher in the disadvantaged cases than in the leading cases in the (joint) communities.

Table 2. Average population and proportion of elderly people of the communities of selected Facebook pages.

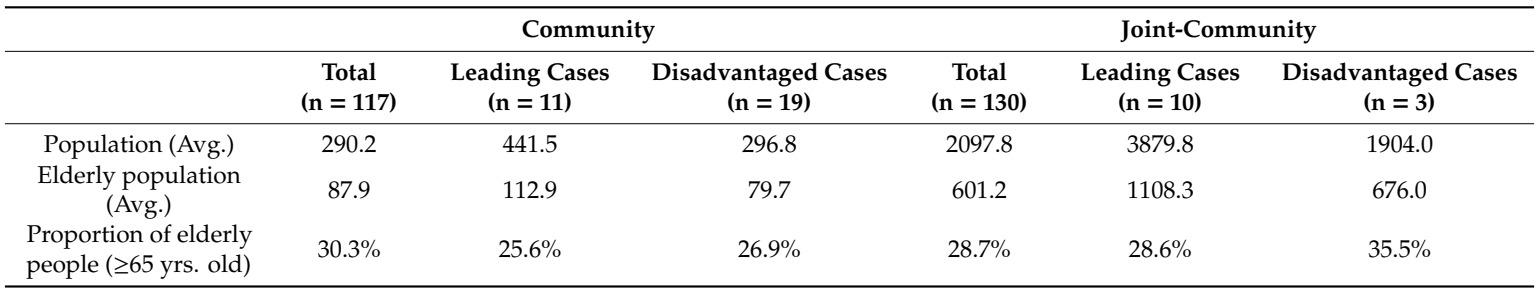

\subsection{Semi-Structured Interviews for the Leading Cases}

Results from the systematic search and the selection of pages revealed that few (joint) communities could start and use Facebook pages effectively for community promotion. Understanding the challenges and successes of these communities in detail could provide important insights for future policy design. Targeting the leading cases, I conducted semi-structured interviews with the key individuals of Facebook pages that had more than 500 "likes." Eleven of these pages were at the community level and 10 were at the joint-community level. I contacted the founders or managers of these pages and received responses from 7 of the 11 pages at the community level and from 7 of the 10 pages at the joint-community level. The summary of these results is shown in Tables 3 and 4 . 
Table 3. Results of semi-structured interviews targeting leading cases at the community level. An ID starting with " $\mathrm{L}$ " denotes leading cases. Two numbers in parentheses in the first row denote population and proportion of elderly people, respectively.

\begin{tabular}{|c|c|c|c|c|c|c|c|}
\hline ID & $\begin{array}{l}\text { "Likes" } \\
\text { (2015) }\end{array}$ & $\begin{array}{l}\text { Founded } \\
\text { Year }\end{array}$ & Key Actors & Age & Status & Knowledge/Skill & Process \\
\hline $\begin{array}{c}\text { L1 } \\
(1187 / 25.9) \\
\end{array}$ & 2476 & 2011 & Insider & $30 \mathrm{~s}$ & Community promotor & Photography/ICT & $\begin{array}{l}\text { He founded and posted on the page for } \\
\text { promotion of the community on his own. }\end{array}$ \\
\hline $\begin{array}{c}\text { L2 } \\
(1891 / 19.9)\end{array}$ & 1178 & 2012 & Outsider & $30 \mathrm{~s}$ & Marketer & Web marketing/ICT & $\begin{array}{l}\text { He was born in the community but had lived } \\
\text { in Tokyo since he was } 16 \text { years old. He } \\
\text { founded and posted on the page. }\end{array}$ \\
\hline $\begin{array}{c}\text { L3 } \\
(62 / 41.9)\end{array}$ & 650 & 2012 & $\begin{array}{l}\text { (Temporary) } \\
\text { Migrant } \\
\text { Insider }\end{array}$ & $30 \mathrm{~s}$ & $\begin{array}{l}\text { Supporter } \\
\text { Community leader }\end{array}$ & ICT & $\begin{array}{l}\text { The older leader had considered networking } \\
\text { with outsiders since the community was hit by } \\
\text { a massive earthquake in } 2004 \text { and asked the } \\
\text { younger supporter to found the page. } \\
\text { A couple of migrants posted on the page. }\end{array}$ \\
\hline $\begin{array}{c}\mathrm{L} 4 \\
(61 / 24.6)\end{array}$ & 1083 & 2012 & Migrant & $20 \mathrm{~s}$ & $\begin{array}{l}\text { Non-profit } \\
\text { organization }\end{array}$ & Promotion/ICT/Photography & $\begin{array}{l}\text { She first came to the community as a member } \\
\text { of a support team following a } 2004 \text { earthquake } \\
\text { She migrated to the community and founded } \\
\text { and posted on the page. }\end{array}$ \\
\hline $\begin{array}{c}\text { L5 } \\
(446 / 26.5)\end{array}$ & 756 & 2012 & $\begin{array}{l}\text { Outsider } \\
\text { Insider }\end{array}$ & $\begin{array}{l}30 \mathrm{~s}-50 \mathrm{~s} \\
50 \mathrm{~s}\end{array}$ & $\begin{array}{l}\text { Researchers } \\
\text { Public officer }\end{array}$ & ICT/regional revitalization & $\begin{array}{l}\text { A research team from university founded the } \\
\text { page and gave lectures about SNSs to } \\
\text { inhabitants. Some inhabitants, including a } \\
\text { local government officer, posted on it. }\end{array}$ \\
\hline $\begin{array}{c}\text { L6 } \\
(112 / 60.7)\end{array}$ & 622 & 2012 & Migrant & unknown & Agricultural union & & $\begin{array}{l}\text { He founded the page for promotion of local } \\
\text { specialty products, and members of the union } \\
\text { posted on the page after self-learning. }\end{array}$ \\
\hline $\begin{array}{c}\text { L7 } \\
(48 / 52.1)\end{array}$ & 736 & 2014 & Migrant & $50 \mathrm{~s}$ & Fishery/Photographer & Photography/ICT & $\begin{array}{l}\text { He founded and posted on the page for } \\
\text { promotion of the community on his own. }\end{array}$ \\
\hline
\end{tabular}


Table 4. Results of semi-structured interviews targeting leading cases at the joint-community level. An ID starting with "L" denotes leading cases. Two numbers in parentheses in the first row denote population and proportion of elderly people, respectively.

\begin{tabular}{|c|c|c|c|c|c|c|c|}
\hline ID & $\begin{array}{l}\text { "Likes" } \\
\text { (2015) }\end{array}$ & $\begin{array}{l}\text { Founded } \\
\text { Year }\end{array}$ & $\begin{array}{l}\text { Key } \\
\text { Actors }\end{array}$ & Age & Status & Knowledge/Skill & Process \\
\hline $\begin{array}{c}\text { L8 } \\
(608 / 36.5)\end{array}$ & 2257 & 2011 & Migrant & $30 \mathrm{~s}$ & & $\begin{array}{l}\text { Promotion/Regional } \\
\text { revitalization }\end{array}$ & $\begin{array}{l}\text { He founded and posted on a website and the page to promote the joint } \\
\text { community after the Great East Japan Earthquake in } 2011 .\end{array}$ \\
\hline $\begin{array}{c}\text { L9 } \\
(1802 / 20.6)\end{array}$ & 500 & 2012 & Outsider & $20 \mathrm{~s}-40 \mathrm{~s}$ & & Design/ICT/Promotion & $\begin{array}{l}\text { A support team for restoration after the Great East Japan Earthquake in } \\
2011 \text { founded the page and a member who had lived in Tokyo posted on it. }\end{array}$ \\
\hline $\begin{array}{c}\text { L10 } \\
(4177 / 25.4)\end{array}$ & 590 & 2011 & $\begin{array}{l}\text { Insider } \\
\text { Insider }\end{array}$ & $\begin{array}{l}40 \mathrm{~s} \\
40 \mathrm{~s}\end{array}$ & $\begin{array}{c}\text { Volunteer } \\
\text { ICT Engineer }\end{array}$ & $\begin{array}{l}\text { Photography } \\
\text { ICT }\end{array}$ & $\begin{array}{l}\text { The older volunteer made a plan and asked an ICT engineer to found the } \\
\text { page. They were part of a volunteer promotional team of the joint } \\
\text { community, and the members posted on the page. }\end{array}$ \\
\hline $\begin{array}{c}\text { L11 } \\
(537 / 36.9)\end{array}$ & 1066 & 2011 & $\begin{array}{l}\text { Outsider } \\
\text { Insider }\end{array}$ & $\begin{array}{l}30 \mathrm{~s} \\
50 \mathrm{~s}\end{array}$ & $\begin{array}{l}\text { Acquaintance } \\
\text { Chamber of } \\
\text { Commerce and } \\
\text { Industry }(\mathrm{CCI})\end{array}$ & $\begin{array}{c}\text { ICT } \\
\text { Promotion/SNS }\end{array}$ & $\begin{array}{l}\text { A friend of a visitor founded the page, and five inhabitants who worked } \\
\text { for CCI posted on it. The older inhabitant asked a woman to host a series } \\
\text { of lectures about using Facebook. }\end{array}$ \\
\hline $\begin{array}{c}\text { L12 } \\
(2158 / 30.7)\end{array}$ & 1073 & 2012 & Insider & $30 \mathrm{~s}$ & Business owner & & $\begin{array}{l}\mathrm{CCI} \text { held a series of seminars about the Internet, suggesting that some } \\
\text { participants start a page for the community. A married couple who } \\
\text { attended the lectures posted on it to promote the joint community. }\end{array}$ \\
\hline $\begin{array}{c}\text { L13 } \\
(4091 / 25.9)\end{array}$ & 508 & 2014 & $\begin{array}{l}\text { Outsider } \\
\text { Outsider } \\
\text { Migrant }\end{array}$ & $\begin{array}{l}\text { unknown } \\
\text { 20s } \\
20 s-30 s\end{array}$ & $\begin{array}{l}\text { Local government } \\
\text { Art school } \\
\text { students }\end{array}$ & $\begin{array}{l}\text { SNS/Promotion } \\
\text { SNS/Design } \\
\text { SNS/Design }\end{array}$ & $\begin{array}{l}\text { A local government official suggested the association for the promotion of } \\
\text { regional development to found the page. The association asked students } \\
\text { or migrants who had come to support the joint community following } \\
\text { heavy rains in } 2004 \text { to post on the page. }\end{array}$ \\
\hline
\end{tabular}


Many of these pages were founded in 2011 and 2012, when Facebook began gaining popularity in Japan. Most of the founders were relatively young $(<40$ years of age). Including the results at both levels, six pages were founded by outsiders (i.e., someone not currently living in the community) and three were managed by outsiders, many of whom had special skills or knowledge in ICT, related promotional skills, or other creative experience. Roles of migrants were also shown to be important as five pages were founded by migrants possessing ICT skills, related promotional skills, or photography experience. For example, L3 was founded by a migrant who was asked to do so by a motivated community leader who had no personal Facebook skills himself. I could find only three pages that were founded by insiders and of these pages, two (L10 and L12) were founded by native inhabitants and the third (L1) was founded by someone who studied outside of the community but returned in order to engage in community revitalization activities. Another page (L10) was founded and managed by two inhabitants with special skills in photography. The managers of L1 and L10 were engaged not only in Facebook, but also in other activities focused on community engagement, such as contributions to other websites and regional magazines. The current manager of L12 said that he and his wife did not have any special skills related to SNSs or promotion but that the community hosted a famous local festival and the name of the community is known nationwide because of it. This original popularity is one big reason why this particular page had received so many "likes" and fans.

From another point of view, 5 out of the 14 pages were managed by disaster-stricken communities. After experiencing natural disasters, the national government implemented programs to bring external supporters to affected areas for help. In other cases, voluntary support teams were formed, who founded Facebook pages in order to report and revitalize the communities through information-sharing.

\subsection{Semi-Structured Interviews for the Particularly Disadvantaged Cases}

Following analysis on the leading cases, it was evident that the power of creative outsiders, including migrants, was strong in many of these cases. Among other cases, there were pages that had been founded and managed by communities located in the most disadvantaged locations, where it is not typically easy for these communities to communicate with outsiders, nor do they receive support from outsiders or governments. Targeting the most disadvantaged cases, I conducted semi-structured interviews using the same methods as with the leading cases.

After targeted search and selection, 19 pages were chosen at the community level and three at the joint-community level. I contacted the founders or managers and received responses from 12 of the 19 pages at the community level and from two of the three pages at the joint-community level. Results are shown in Tables 5 and 6 (noting that D2 and D8 were identical to pages used in the selection of the leading cases and will not be included in this section's analysis). 
Table 5. Summary of the results of semi-structured interviews targeting the most disadvantaged cases at the community level. An ID starting with “ $\mathrm{D}$ " corresponds to particularly disadvantaged cases. Two numbers in parentheses in the first row denote population and proportion of elderly people, respectively.

\begin{tabular}{|c|c|c|c|c|c|c|c|}
\hline ID & “Likes” (2015) & Founded Year & Key Actors & Age & Status & Knowledge/Skill & Process \\
\hline $\begin{array}{c}\mathrm{D} 1 \\
(102 / 52.9)\end{array}$ & 79 & 2011 & Insider & $40 \mathrm{~s}$ & Local leader & SNS & $\begin{array}{l}\text { He founded and posted on the page to } \\
\text { promote the community on his own. }\end{array}$ \\
\hline D2 & 1178 & 2012 & \multicolumn{5}{|c|}{ The same community as L2 } \\
\hline $\begin{array}{c}\text { D3 } \\
(147 / 41.5)\end{array}$ & 96 & 2013 & Insider & $30 \mathrm{~s}$ & Local farmer & & $\begin{array}{l}\text { He founded and posted on the page to } \\
\text { promote the community on his own. }\end{array}$ \\
\hline $\begin{array}{c}\mathrm{D} 4 \\
(550 / 30.9)\end{array}$ & 161 & 2012 & Outsider & $20 \mathrm{~s}$ & $\begin{array}{l}\text { Local government } \\
\text { official }\end{array}$ & Promotion & $\begin{array}{l}\text { He founded and posted on the page to } \\
\text { promote the community on his own. }\end{array}$ \\
\hline $\begin{array}{c}\text { D5 } \\
(137 / 38.0)\end{array}$ & 199 & 2013 & Outsider & $40 \mathrm{~s}$ & Volunteer & & $\begin{array}{l}\text { He founded and posted on the page to report } \\
\text { the situation of the community after a heavy } \\
\text { rain in } 2011 \text { on his own. }\end{array}$ \\
\hline $\begin{array}{c}\mathrm{D} 6 \\
(137 / 38.0)\end{array}$ & 133 & 2012 & Outsider & $50 \mathrm{~s}$ & Local government & & $\begin{array}{l}\text { He founded and posted on the page to } \\
\text { promote the community on his own. }\end{array}$ \\
\hline $\begin{array}{c}\mathrm{D} 7 \\
(138 / 29.0)\end{array}$ & 74 & 2014 & Insider & $40 \mathrm{~s}$ & Regional organization & SNS & $\begin{array}{l}\text { He founded and posted on the page to } \\
\text { promote the community on his own. }\end{array}$ \\
\hline D8 & 622 & 2012 & \multicolumn{5}{|c|}{ The same community as L6 } \\
\hline $\begin{array}{c}\mathrm{D} 9 \\
(42 / 35.7)\end{array}$ & 101 & 2013 & $\begin{array}{l}\text { Insider } \\
\text { Outsider }\end{array}$ & $60 \mathrm{~s}$ & $\begin{array}{l}\text { Regional organization } \\
\text { Local government }\end{array}$ & & $\begin{array}{l}\text { The regional organization founded and } \\
\text { posted on the page to promote the } \\
\text { community by asking local government to } \\
\text { support the activity. }\end{array}$ \\
\hline $\begin{array}{c}\mathrm{D} 10 \\
(148 / 54.1)\end{array}$ & 239 & 2012 & Insider & & Regional organization & & $\begin{array}{l}\text { The organization founded and posted on the } \\
\text { page to promote the community. }\end{array}$ \\
\hline $\begin{array}{c}\text { D11 } \\
(129 / 27.9)\end{array}$ & 82 & 2013 & Insider & $50 \mathrm{~s}$ & Local organization & Programming/ICT & $\begin{array}{l}\text { He founded and posted on the page to } \\
\text { promote the community on his own. }\end{array}$ \\
\hline $\begin{array}{c}\mathrm{D} 12 \\
(951 / 20.0)\end{array}$ & 225 & 2012 & Insider & $70 \mathrm{~s}$ & Local leader & & $\begin{array}{l}\text { He worked for local government and } \\
\text { founded and posted on the page to promote } \\
\text { community revitalization and networking. }\end{array}$ \\
\hline
\end{tabular}


Table 6. Summary of the results of semi-structured interviews targeting the most disadvantaged cases at the joint-community level. An ID starting with " $\mathrm{D}$ " corresponds to particularly disadvantaged cases. Two numbers in parentheses in the first row denote population and proportion of elderly people, respectively.

\begin{tabular}{|c|c|c|c|c|c|c|c|}
\hline ID & “Likes” (2015) & Founded Year & Key Actors & Age & Status & Knowledge/Skill & Process \\
\hline $\begin{array}{c}\mathrm{D} 13 \\
(1188 / 41.5)\end{array}$ & 137 & 2014 & $\begin{array}{l}\text { Insider } \\
\text { Outsider }\end{array}$ & $\begin{array}{c}\text { 20s } \\
\text { Unknown }\end{array}$ & $\begin{array}{c}\text { Local organization } \\
\text { Non-profit organization } \\
\text { (NPO) }\end{array}$ & ICT/SNS & $\begin{array}{l}\text { An inhabitant founded the page with NPO } \\
\text { support. He and another person in charge of } \\
\text { promotion in the NPO posted on the page to } \\
\text { promote the community on their own. }\end{array}$ \\
\hline $\begin{array}{c}\mathrm{D} 14 \\
(2372 / 34.5)\end{array}$ & 78 & 2011 & Insider & $30 \mathrm{~s}$ & Local organization & SNS & $\begin{array}{l}\text { He founded and posted on the page to } \\
\text { promote the community on his own. }\end{array}$ \\
\hline
\end{tabular}


Many of these pages were founded in 2012 and 2013, following the start of Facebook's popularity in Japan. Eight out of the final 12 pages were founded by inhabitants who lived within each community, many of whom did not have special knowledge about nor skills related to promotion, but some did have experience using SNSs personally. Only one (D10) of these pages, except D2 and D8, had more "likes" than the average (230.9). In many cases, the founders posted to and managed the pages by themselves, as they had no other supporters. Of the other four pages, only two (D5 and D6) were founded by outsiders. D5 was founded by a volunteer who came to the community as part of a support team focused on restoration following a natural disaster. D6 was founded by a local government and while the founders were outsiders, neither had special skills or experience in ICT or promotion. The remaining two pages (D9 and D13) were founded by insiders with support from outsiders (local government and/or a non-profit organization (NPO)), but in D9, neither the insider nor outsider had relevant skills or experience. In D13, support from outside was available, but the number of "likes" remained low.

Figure 7 shows the comparison of knowledge/skills of key actors between the leading and particularly disadvantaged cases.

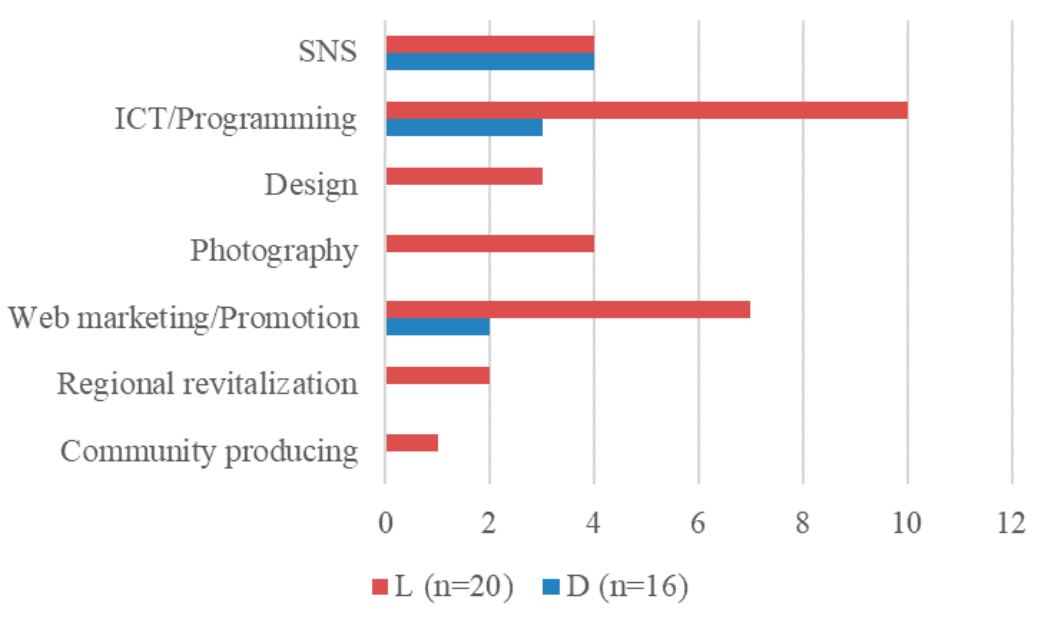

Figure 7. Comparison of key actors' knowledge/skills between leading (L) and particularly disadvantaged (D) cases. Two actors overlap.

Obviously, key actors of leading cases had a variety of knowledge/skills compared with ones of particularly disadvantaged cases. The numbers of key actors with knowledge of SNS is the same, while most of the other knowledge/skills are held by key actors of leading cases. The biggest gaps were observed in ICT/programming and web marketing/promotion.

\subsection{Consequences of Founding and Maintaining a Facebook Page}

For rural development, adoption and use of Facebook is not sufficient by itself to serve as social innovation, so focusing on the consequences of Facebook use is necessary to guide future policy. Table 7 shows subjective consequences of the adoption and use of Facebook for the selected pages.

The findings were categorized into eight groups, with many pages from both the leading cases and disadvantaged cases reporting that contacts and communication online dramatically increased. This was followed in commonality by community information being shared with those who had migrated away from the community. In addition, appearances on TV or other media increased and other regional organizations adopted Facebook after being influenced by the pages. Attention should also be paid to the consequence wherein the number of tourists and visitors increased, local services or businesses were promoted, and migration or migration requests to the community increased. These factors were reported only by the leading cases. Conversely, there were three cases that did not experience any positive effects from having a Facebook page, all of which were in the particularly disadvantaged cases 
group. In total, while many pages saw similar effects from the adoption and use of Facebook, different tendencies and trends were found between the leading and particularly disadvantaged cases.

Table 7. Assessments of potential impacts of Facebook use as described by the interviewees.

\begin{tabular}{|c|c|}
\hline Consequences & Cases \\
\hline Contacts/Communication online increased & $\begin{array}{l}\text { L2, L3, L4, L5, L6, L7, L10, L11, } \\
\text { L14, D1, D4, D6, D11, D13, D14 }\end{array}$ \\
\hline Tourists/Visitors increased & L1, L8, L13, L14 \\
\hline Community information was conveyed to those who had migrated from the community & L1, L3, L5, L9, L10, D4, D12 \\
\hline Appearances on TV or other media increased & L1, L8, D3, D7 \\
\hline Local services or businesses were promoted & L1, L8 \\
\hline Migration or migration requests to the community increased & L7 \\
\hline Other regional organizations adopted Facebook after being influenced by the page & L2, L9, D1 \\
\hline No effects & D5, D9, D10 \\
\hline
\end{tabular}

\section{Discussion}

\subsection{Overall Adoption and Use of Facebook in Disadvantaged Rural (Joint) Communities in Japan}

In Japan, the Internet is available nationwide, even in most peripheral areas. However, this study found that adoption of Facebook at the (joint) community level was still rare among disadvantaged rural areas. As innovation diffusion theory states that $2.5 \%$ of the earliest adopters are categorized as "innovators" [59], these (joint) communities are considered to be innovators among all the disadvantaged communities in Japan. Furthermore, founders of all the Facebook pages analyzed in this study are also considered to be innovators within the communities.

While few rural communities have adopted Facebook, those that have seemed to face challenges in taking advantage of Facebook for information-sharing or community promotion after adoption. Among the pages analyzed in this study, few of them had received wide attention online. This indicates that the digital divide between rural and urban areas cannot be solved by establishing infrastructure alone. This is consistent with Blank, Graham, and Calvino [15], who indicated that demographic factors have more of an impact on the digital divide than connectivity. While SNSs have become a fundamental tool for organizational or regional communication and promotion, more penetration of SNSs might escalate the second-level digital divide between disadvantaged rural areas and urban areas [9-12,44].

\subsection{The Roles of Internal or External Key Actors in Adoption and Effective Use of Social Media}

To further examine key actors' characteristics and the actual process of adoption and use of social media in disadvantaged rural communities, this study conducted case studies. The analysis of case study data revealed differences in the types of collaboration systems used, even among the leading cases and certainly between the leading and particularly disadvantaged cases (see Figure 8).

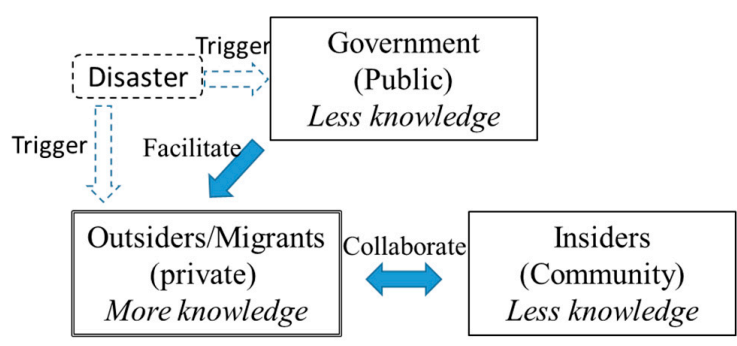

(a)

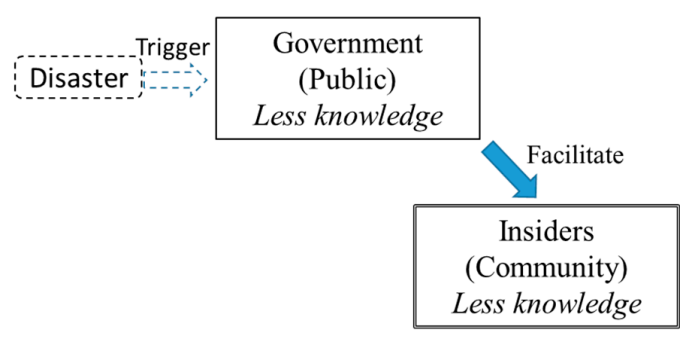

(b)

Figure 8. Differences of the collaboration (nexus) system between the leading cases and the particularly disadvantaged cases. (a) The leading cases; (b) The particularly disadvantaged cases 
Findings from the leading cases indicate that these pages were commonly founded and empowered by outsiders who were relatively young. These outsiders can be considered change agents [59] since the outsiders had skills, knowledge, and experience that were not available within the community. In particular, those skills related to promotion/marketing or photography, as skills in only ICT/SNS did not seem to lead to the acquisition of many fans on the pages. These outsiders can also be considered creatives who tend to pursue quality of life or creative inspiration, as designated in past studies [52-54]. This study also found that as migrants, the creative outsiders could turn to insiders for support. Their migration enables rural communities to continuously have power and support, which could be an ideal way for rural communities to go online.

Additionally, attention should be paid to cases where Facebook use resulted after the community had been stricken by a natural disaster such as the Great East Japan Earthquake. As these types of natural disasters are not rare in Japan (e.g., flooding), support teams and governmental support programs are frequently implemented. Mass media reporting on these situations can highlight these small communities that may otherwise be unknown to citizens who live far from these disadvantaged rural areas, particularly those communities located in peripheral regions. Ironically, such disasters became catalysts that drew public attention to peripheral rural communities, which led to them going online.

In several cases, I identified creative members who had special skills, knowledge, and experience with ICT or promotion within a community. The role of insiders is preferable for continual support and management of the pages, though availability of such skillful people within a community is a matter of luck in disadvantaged rural communities. In this study, those insiders sometimes collaborated with outsiders. Compared to the outsiders, the insiders were older and self-identified as having limited knowledge of ICT, but they did have strong motivation for community revitalization, which facilitated outsiders' activities.

Findings from the most disadvantaged cases show different trends than those seen in leading cases. More than half of these cases were founded by insiders, but the founders tended not to have special creative skills or experience in using ICT or seeking support from outsiders, as in the leading cases. As a result, these pages did not acquire many fans, except for the two communities that were also listed in the leading cases (D2 and D8). Additionally, personal experience in social media did not seem to be effective for regional promotion since promotion on social media requires not only technical skills but also creative senses, such as design. These tendencies reflected the criteria for the selection of the most disadvantaged communities, those that were not expected to have official support from the outside.

As for external supporters of the most disadvantaged communities, in most cases, they were local governments or NPOs, as these groups had motivation or a responsibility for regional growth, and so they tried to introduce new technology, such as SNSs, to rural communities. However, they could not become true change agents because they often lacked knowledge or skills related to ICT as well as effective ways of regional promotion, which led to less effective adoption of technology. This finding could support a conclusion of Neumeier's [25] study, "Social innovation in rural development cannot be easily initiated or steered from the top down" (p. 43).

\subsection{Consequences of Social Media Adoption and Use in the Context of Social Innovation}

This study's findings revealed some consequences experienced by (joint) communities that had adopted Facebook. Many pages from both the leading cases and disadvantaged cases reported that contacts and communication increased. This indicates that adoption of Facebook has the potential for activating online communication and networking, which can contribute to the building of social capital. This result supports past debates that the Internet can facilitate social capital, at the individual level [12] and at the enterprise level [55], in rural areas. Community information was also shared with those who had out-migrated from the community. This may facilitate information-sharing with out-migrants who know the community well, inviting their contributions to local rural development. Appearances 
on social media also facilitated promotion of local services or businesses not only through the Internet but also through other mass media, such as TV, bringing economic benefits to the communities, as Bos and Owen [67] observed. In five of the leading cases, Facebook contributed to the increase of tourists or migrants. This implies that effective use of social media facilitates not only online communication but also offline contacts.

This study could not carry out analysis to find any evidence that social media facilitates knowledge-sharing and other practical collaboration among internal and external actors. This study mainly found that social media achieves the process dimension of social innovation. The outcome dimension of social innovation requires further investigation [25].

\subsection{Recommendations for Future Policy Design for Rural Sustainability Considering ICT}

To conclude, based on the obtained findings, this study has provided insights for policy design. When considering ICT in rural development, connectivity is the priority issue for governments. However, this study confirmed it is not sufficient in the case of Japan and its high level of connectivity.

Furthermore, while internal innovators are important for peripheral rural communities to go online, they are rarely available in disadvantaged rural communities. Bringing educational opportunities to rural inhabitants is still essential, but the findings indicate that internal innovators are often insufficient without change agents who have not only technical skills but also artistic skills and knowledge. Since it is not easy for older rural inhabitants to acquire those artistic skills and knowledge in a short period, governments should play an important yet indirect role by encouraging external assistance for communities and stimulating policy programs that support and facilitate change agents, especially those with creative skills and knowledge from the private sector, to go into disadvantaged rural communities. Governments themselves should remain connectors [68] since they often do not have advanced knowledge and skills of online activities themselves. This may often be a difficult task because the public sector has been pressured to cut funding for various initiatives, so massive disasters might have given them reasons to support the disadvantaged communities.

In reality, many rural communities in Japan have been in similar situations to the most disadvantaged cases in this study. What can they do to achieve social innovation through ICT? This study suggests that they work with governments to look for suitable and achievable ways to attract creative outsiders, which would be more effective than trying to be innovators on their own. Furthermore, change agents should never focus only on the adoption phase. The utilization phase is also critical to the communities' achievement of positive consequences from the utilization of ICT. It is also important to provide creatives with comfortable environments to fully use their skills [52].

\section{Conclusions}

This study revealed the degree to which disadvantaged rural communities have adopted Facebook as an innovation throughout Japan and how the adoption was realized. Comprehensive data at the national level, targeting Internet adoption of disadvantaged rural communities nationwide, have not yet been explored in Japan nor included in worldwide debates of rural studies. This study also contributes some evidence for previous theoretical and empirical notions regarding social innovation at the national level. I believe that these findings and implications are useful not only for Japan but also for other countries that are expected to mirror Japan in terms of experiencing serious aging and depopulation in rural areas in the future. Hopefully, more diffusion of ICT and other advanced technology will open the gate to future sustainable rural communities by activating social innovation

This study is expected to contribute to the comprehensive understanding of social media adoption in disadvantaged rural communities, which has previously gone unexamined. Limitations, however, include that this study only focused on Facebook as representative social media, due to financial and temporal constraints, but there are a number of other such media available online. Focus on some of these other tools should be included in future research. In addition, this study did not analyze actual posted contents and communication data, such as the number of posts and responses to the 
posts. Future study needs to quantitatively analyze these data using text mining or machine learning approaches. Furthermore, this study could not focus on cases other than the leading cases and the most disadvantaged cases. Other pages may provide valuable insights and further analysis using more comprehensive data is expected.

Author Contributions: K.O. formulated the research design, conducted the field survey, collected data, analyzed the data, and wrote the paper.

Funding: This work was supported by the Ministry of Land, Infrastructure, Transport and Tourism (grant number 10014160015).

Acknowledgments: We would like to thank all the respondents who participated in the lengthy interviews. We also thank Ryu Tamai, a bachelor student at the time of the survey, for assisting with the semi-structured interviews and data aggregation.

Conflicts of Interest: The author declares no conflict of interest. The funders had no role in the design of the study; in the collection, analyses, or interpretation of data; in the writing of the manuscript, or in the decision to publish the results.

\section{References}

1. Dargan, L.; Shucksmith, M. LEADER and innovation. Sociol. Rural. 2008, 48, 274-291. [CrossRef]

2. Neumeier, $\mathrm{S}$. Why do social innovations in rural development matter and should they be considered more seriously in rural development research? Proposal for a stronger focus on social innovations in rural development research. Sociol. Rural. 2012, 52, 48-69. [CrossRef]

3. Bock, B.B. Rural marginalisation and the role of social innovation; A turn towards nexogenous development and rural reconnection. Sociol. Rural. 2016, 56, 552-573. [CrossRef]

4. Leeuwis, C.; Aarts, N. Rethinking communication in innovation processes: Creating space for change in complex systems. J. Agric. Educ. Ext. 2011, 17, 21-36. [CrossRef]

5. Bosworth, G.; Annibal, I.; Carroll, T.; Price, L.; Sellick, J.; Shepherd, J. Empowering local action through neo-endogenous development; The case of LEADER in England. Sociol. Rural. 2016, 56, 427-449. [CrossRef]

6. Salemink, K.; Strijker, D.; Bosworth, G. Rural development in the digital age: A systematic literature review on unequal ICT availability, adoption, and use in rural areas. J. Rural Stud. 2017, 54, 360-371. [CrossRef]

7. Townsend, L.; Sathiaseelan, A.; Fairhurst, G.; Wallace, C. Enhanced broadband access as a solution to the social and economic problems of the rural digital divide. Local Econ. 2013, 28, 580-595. [CrossRef]

8. Malecki, E.J. Digital development in rural areas: Potentials and pitfalls. J. Rural Stud. 2003, 19, 201-214. [CrossRef]

9. Barzilai-Nahon, K. Gaps and bits: Conceptualizing measurements for digital divide/s. Inf. Soc. 2006, 22, 269-278. [CrossRef]

10. Selwyn, N. Reconsidering political and popular understandings of the digital divide. New Media Soc. 2004, 6, 341-362. [CrossRef]

11. Van Dijk, J.A.G.M. Digital divide research, achievements and shortcomings. Poetics 2006, 34, 221-235. [CrossRef]

12. Stern, M.J; Adams, A.E.; Elsasser, S. Digital inequality and place: The effects of technological diffusion on internet proficiency and usage across rural, suburban, and urban counties. Sociol. Inq. 2009, 79, 391-417. [CrossRef]

13. Ashmore, F.H.; Farrington, J.H.; Skerratt, S. Superfast broadband and rural community resilience: Examining the rural need for speed. Scott. Geogr. J. 2015, 131, 265-278. [CrossRef]

14. Morris, W.; Henley, A.; Dowell, D. Farm diversification, entrepreneurship and technology adoption: Analysis of upland farmers in Wales. J. Rural Stud. 2017, 53, 132-143. [CrossRef]

15. Blank, G.; Graham, M.; Calvino, C. Local geographies of digital inequality. Soc. Sci. Comput. Rev. 2018, 36, 82-102. [CrossRef]

16. Leeuwis, C. Communication for Rural Innovation: Rethinking Agricultural Extension; Blackwell Publishing: Oxford, UK, 2013.

17. McLure Wasko, M.; Faraj, S. Why should I share? Examining social capital and knowledge contribution in electronic networks of practice. MIS Q. 2005, 29, 35-57. [CrossRef]

18. Ministry of Internal Affairs and Communication. The 2017 White Paper on Information and Communications in Japan. 2017. Available online: http://www.soumu.go.jp/johotsusintokei/whitepaper/eng/WP2017/chapter6.pdf\#page $=1$ (accessed on 18 March 2019). 
19. Ministry of Internal Affairs and Communication. The Development Status of Broadband Infrastructure. 2017. Available online: http://www.soumu.go.jp/main_content/000371278.pdf (accessed on 18 March 2019). (In Japanese)

20. Ministry of Internal Affairs and Communication. The Communication Usage Trend Survey 2014. 2014. Available online: http://www.soumu.go.jp/johotsusintokei/statistics/pdf/HR201400_001.pdf (accessed on 18 March 2019). (In Japanese)

21. Neely, C. Japan's Top Social Media Networks for 2016. 2016. Available online: http://www.humblebunny. com/ja/top-social-media-networks-in-japan-2015-year-in-review/ (accessed on 18 March 2019).

22. Schumpeter, J.A. Capitalism, Socialism and Democracy; Harper \& Row: New York, NY, USA, 1942.

23. Pol, E.; Ville, S. Social innovation: Buzz word or enduring term? J. Socio-Econ. 2009, 38, 878-885. [CrossRef]

24. Bock, B.B. Social innovation and sustainability; How to disentangle the buzzword and its application in the field of agriculture and rural development. Stud. Agric. Econ. 2012, 114, 57-63. [CrossRef]

25. Neumeier, S. Social innovation in rural development: Identifying the key factors of success. Geogr. J. 2017, 183, 34-46. [CrossRef]

26. Rover, O.J.; De Gennaro, B.C.; Roselli, L. Social innovation and sustainable rural development: The case of a Brazilian agroecology network. Sustainability 2016, 9, 3. [CrossRef]

27. Richter, R. Rural social enterprises as embedded intermediaries: The innovative power of connecting rural communities with supra-regional networks. J. Rural Stud. 2018. [CrossRef]

28. Onitsuka, K.; Hoshino, S. Inter-community networks of rural leaders and key people: Case study on a rural revitalization program in Kyoto Prefecture, Japan. J. Rural Stud. 2018, 61, 123-136. [CrossRef]

29. Noack, A.; Federwisch, T. Social innovation in rural regions: Urban impulses and cross-border constellations of actors. Sociol. Rural. 2017, 59, 92-112. [CrossRef]

30. Nonaka, I. A dynamic theory of organizational knowledge creation. Organ. Sci. 1994, 5, 14-37. [CrossRef]

31. Wenger, E. Communities of Practice: Learning, Meaning, and Identity; Cambridge University Press: Cambridge, UK, 1999.

32. Huysman, M.; de Wit, D. Practices of managing knowledge sharing: Towards a second wave of knowledge management. Knowl. Process Manag. 2004, 11, 81-92. [CrossRef]

33. Nahapiet, J.; Ghoshal, S. Social capital, intellectual capital, and the organizational advantage. Acad. Manag. Rev. 1998, 23, 242-266. [CrossRef]

34. Wellman, B.; Haase, A.Q.; Witte, J.; Hampton, K. Does the internet increase, decrease, or supplement social capital? Am. Behav. Sci. 2001, 45, 436-455. [CrossRef]

35. Ellison, N.B.; Steinfield, C.; Lampe, C. The benefits of Facebook "friends:" Social capital and college students' use of online social network sites. J. Comput. Mediat. Commun. 2007, 12, 1143-1168. [CrossRef]

36. Wenger, E.; White, N.; Smith, J. Digital Habitats: Stewarding Technology for Communities; CPsquare: Portland, OR, USA, 2009.

37. Castells, M. The Network Society: A Cross-Cultural Perspective; Edward Elgar Pub: Cheltenham, UK, 1996.

38. Blanks Hindman, D. The rural-urban digital divide. J. Mass Commun. Q. 2000, 77, 549-560.

39. Strover, S. Rural internet connectivity. Telecommun. Policy 2001, 25, 331-347. [CrossRef]

40. Whitacre, B.E.; Mills, B.F. Infrastructure and the rural-urban divide in high-speed residential internet access. Int. Reg. Sci. Rev. 2007, 30, 249-273. [CrossRef]

41. Whitacre, B.; Gallardo, R.; Strover, S. Does rural broadband impact jobs and income? Evidence from spatial and first-differenced regressions. Ann. Reg. Sci. 2014, 53, 649-670. [CrossRef]

42. Townsend, L.; Wallace, C.; Fairhurst, G. "Stuck out here": The critical role of broadband for remote rural places. Scott. Geogr. J. 2015, 131, 171-180. [CrossRef]

43. Philip, L.; Cottrill, C.; Farrington, J.; Williams, F.; Ashmore, F. The digital divide: Patterns, policy and scenarios for connecting the "final few" in rural communities across Great Britain. J. Rural Stud. 2017, 54, 386-398. [CrossRef]

44. DiMaggio, P.; Hargittai, E. From the "Digital Divide" to "Digital Inequality": Studying Internet Use as Penetration Increases; Working Paper; Center for Arts and Cultural Policy Studies, Woodrow Wilson School, Princeton University: Princeton, NJ, USA, 2001.

45. Van Deursen, A.J.A.M.; van Dijk, J.A.G.M. The digital divide shifts to differences in usage. New Media Soc. 2014, 16, 507-526. [CrossRef] 
46. Kilpeläinen, A.; Seppänen, M. Information technology and everyday life in ageing rural villages. J. Rural Stud. 2014, 33, 1-8. [CrossRef]

47. Erdiaw-Kwasie, M.O.; Alam, K. Towards understanding digital divide in rural partnerships and development: A framework and evidence from rural Australia. J. Rural Stud. 2016, 43, 214-224. [CrossRef]

48. Park, S. Digital inequalities in rural Australia: A double jeopardy of remoteness and social exclusion. J. Rural Stud. 2017, 54, 399-407. [CrossRef]

49. Stern, M.J.; Adams, A.E. Do rural residents really use the internet to build social capital? An empirical investigation. Am. Behav. Sci. 2010, 53, 1389-1422. [CrossRef]

50. Chowdhury, A.; Odame, H.H. Social media for enhancing innovation in agri-food and rural development: Current dynamics in Ontario, Canada. J. Rural Community Dev. 2014, 8, 97-119.

51. Gilbert, E.; Karahalios, K.; Sandvig, C. The network in the garden: Designing social media for rural life. Am. Behav. Sci. 2010, 53, 1367-1388. [CrossRef]

52. Roberts, E.; Townsend, L. The contribution of the creative economy to the resilience of rural communities: Exploring cultural and digital capital. Sociol. Rural. 2016, 56, 197-219. [CrossRef]

53. Anderson, A.R.; Wallace, C.; Townsend, L. Great expectations or small country living? Enabling small rural creative businesses with ICT. Sociol. Rural. 2016, 56, 450-468. [CrossRef]

54. Townsend, L.; Wallace, C.; Fairhurst, G.; Anderson, A. Broadband and the creative industries in rural Scotland. J. Rural Stud. 2017, 54, 451-458. [CrossRef]

55. Townsend, L.; Wallace, C.; Smart, A.; Norman, T. Building virtual bridges: How rural micro-enterprises develop social capital in online and face-to-face settings. Sociol. Rural. 2016, 56, 29-47. [CrossRef]

56. Galloway, L.; Sanders, J.; Deakins, D. Rural small firms' use of the internet: From global to local. J. Rural Stud. 2011, 27, 254-262. [CrossRef]

57. Yamanaka, M. Factor analysis of development and disparity in regional information systems in an underdeveloped area. J. Socio-Inform. 1999, 11, 69-84. (In Japanese)

58. Onitsuka, K.; Hoshino, S.; Hashimoto, S.; Kuki, Y. Causes of digital divide and possibility to improve such condition in hilly and mountainous areas: Focusing on age, attributes and characteristic features of inhabitants. J. Rural Plan. 2012, 31, 261-266. (In Japanese) [CrossRef]

59. Rogers, E. Diffusion of Innovation, 4th ed.; Free Press: New York, NY, USA, 2010.

60. Eto, A.; Hoshino, S.; Onitsuka, K.; Hashimoto, S. Feasibility of the diffusion of 'real-name' local SNS in rural community: Approach to potential users based on segmentation. J. Rural. Plan. 2014, 32, 499-506. (In Japanese) [CrossRef]

61. Onitsuka, K.; Hoshino, S. The actual situation of information sharing by word of mouth and challenges for the improvement in rural areas: Quantitative study through social network analysis utilizing 2-mode data focusing on receiving organization affiliations. J. Rural Plan. 2015, 34, 67-76. (In Japanese) [CrossRef]

62. Onitsuka, K.; Hoshino, S.; Hashimoto, S.; Kuki, Y. The roles and effects of key persons in promotion process of SNS in rural areas. Pap. Environ. Inf. Sci. 2012, 26, 137-142. (In Japanese)

63. Onitsuka, K.; Hoshino, S.; Hashimoto, S.; Kuki, Y. A sense of region among Internet users in hilly and mountainous areas: A comparison of types of Internet use. J. Rural Probl. 2013, 191, 86-92. (In Japanese)

64. Ministry of Agriculture, Forestry and Fisheries. 2010 World Census of Agriculture and Forestry. Available online: https://www.e-stat.go.jp/en/stat-search/files?page=1\&layout=datalist\&toukei=00500209\& tstat $=000001032920 \&$ cycle $=0 \& t c l a s s 1=000001038546 \& t c l a s s 2=000001049164$ (accessed on 18 March 2019).

65. Sum, S.; Mathews, M.R.; Pourghasem, M.; Hughes, I. Internet technology and social capital: How the internet affects seniors' social capital and wellbeing. J. Comput. Mediat. Commun. 2008, 14, 202-220. [CrossRef]

66. Ministry of Agriculture, Forestry and Fisheries. What Is Hilly and Mountainous Area? Available online: http: //www.maff.go.jp/j/nousin/tyusan/siharai_seido/s_about/cyusan/ (accessed on 11 May 2019). (In Japanese)

67. Bos, E.; Owen, L. Virtual reconnection: The online spaces of alternative food networks in England. J. Rural Stud. 2016, 45, 1-14. [CrossRef]

68. Woods, M. Rural development, globalization and European regional policy: Perspectives from the DERREG Project. Geogr. Pol. 2013, 86, 99-109. [CrossRef]

(C) 2019 by the author. Licensee MDPI, Basel, Switzerland. This article is an open access article distributed under the terms and conditions of the Creative Commons Attribution (CC BY) license (http://creativecommons.org/licenses/by/4.0/). 